DISCUSSION PAPER

\title{
ANALYSING DAIRY OPERATIONS WITH THE INTERACTIVE MODEL OF A DAIRY FARM
}

\author{
Miroslav ZAHRADNIK ${ }^{1 *}$, Jan POKRIVCAK ${ }^{2}$, Marian TOTH ${ }^{2}$
}

\author{
Address: \\ ${ }^{1}$ National Agricultural and Food Centre - Research Institute for Animal Production Nitra (NPPC-RIAP), Slovakia \\ ${ }^{2}$ Slovak University of Agriculture in Nitra, Faculty of Economics and Management, Slovakia \\ Corresponding author's e-mail: zahradnik@vuzv.sk
}

\begin{abstract}
The paper focuses on factors affecting the economics of milk production based on modelling future effects of present managerial decisions. We evaluate a sample Slovak dairy farms from the economic and performance indicator datasets of the National Agricultural and Food Centre - Research institute for animal production Nitra (NPPC-RIAP), referring to semi-intensive dairy farm and typical Holstein dairy farm. The EkonMOD milk decision support tool for dairy farm managers will be used to run various scenarios in heifer replacement strategies. If the average age at first calving (AFC) is reduced from 30 down to 24 months, the dairy could expect additional heifers for potential sale, growth, or culling pressure on the lactating herd. This approach means that in the first two years' heifer development is emphasized, expenses in feed and management are decreased by 47,520€ per year, and 53,750€ worth of heifers are sold, bringing the total potential income for those two years to $101,270 €$. The reduction of AFC in semi-intensive dairy farm in the what-if scenario 1 reduced the number of heifers needed for replacement from 290 to 269 heifers, also having the positive impact on the profitability resulting from these interrelations. In the what-if scenario 2 the AFC remained the same as in what-if scenario 1, meaning that the number of replacements needed was without any change. In the last-different sample farm case scenario presented in this paper, we considered the Holstein dairy farm with 500 productive dairy cows. The reduction in the AFC from 26 to 24 months reduced the number of feeding days in the heifer category by 12 410 feeding days, resulting to the reduction in total costs of at least $22000 €$, in this case.
\end{abstract}

Keywords: dairy farm, milk, decision tool, production

JEL: Q02, Q12, O31

\section{INTRODUCTION}

EU dairy farming systems are increasingly faced to the ongoing structural changes associated with the shift to large intensive systems, being more profitable and competitive in the global level. According to study of Burrell and followed by Dries the smaller, locally operating milk producers and their producer associations diffused all over Europe, are substituted by more concentrated and leading to an almost complete integration of these associations into the integrated downstream cooperative and Multinational corporations (MNC) managed by processing industries (Burrell, 2004; Dries et al., 2009).

EU dairy production can be broadly divided into five main economic-technical systems, however still with significant variation within each system. Intensive high input-output system is dominantly located in Netherlands, England, France, Sweden, Denmark and Germany, accounting for the majority of dairy cow numbers and milk output. The average herd size and stocking rates are relatively high. The average herd age tends to be young which implies a relatively high replacement rates (CEAS, 2010). The key point when considering the optimal housing system, nutrition strategy, microclimatic levels and other related issues is categorisation according to age of animal When considering the animal physiological requirements, the more detailed age categorization into subgroups is needed. The main nutrition-based structure involves calves, heifers and dairy cows (Brestenský and Mihina, 2006). The determination of the nutritional requirements in feed doses for all categories of animals at the dairy farm is following the methodology developed by the NPPC-RIAP Nitra (Petrikovič and Sommer, 2002).

\section{Economic sustainability of dairy production}

The dairy sector, and agriculture in general, faces three key challenges: the need to produce more in order to feed a growing world population, to produce something different (adjust to consumer demands for food and new services) and, last but not least, to produce better (in respect of the environment, ecology and efficient resource use). The latter challenge is often the first to be associated with sustainability, although sustainability comprises not only the environment, but also includes social (people) and economic (profit) dimensions (De Jong, 2013). The importance of animal-source foods in maintaining the health and nutritional status of inhabitants of developing countries, for whom the supply of high-quality protein is often limited, is well recognized. A common description of sustainability is the ability of a system, a firm or a sector to survive in the long run. The concept of resilience 
indicates the ability of a system, firm or sector to maintain its structural and functional capacity after a disturbance or shock (Perrings, 1998). Resilience is evidenced by ability to recover and persist. According to Garmestani et al. (2006) the most resilient industries will be those with functions spread across the range of firm size.

\section{Decision support tools for dairy farm management}

Integrated information tools will be a major contributor in the realization of a sustainable development, although receiving only limited attention in current research generally (Melville, 2010; Korte et al., 2012), and especially in agriculture (Aubert et al., 2012). Agricultural production decision-making is becoming more complex, due in part to increased competition caused by the globalization of agriculture and the need to adopt more sustainable farming practices (Rogers et al. 2004). The decision support tools typically have quantitative output and place emphasis on the end user for final problem solving and decision making (Newman et al. 2000). Software applications can facilitate effective farm management by recording data efficiently, analysing it, and generating a series of evidence-based recommendations. The benefits of using a decision support tools are that it can improve individual productivity, improve decision quality and problem solving, as well as facilitate interpersonal communication. It can also improve decision-making skills and increase organizational control (e.g. Power, 2002; Turban et al., 2007).

Optimal replacement decisions are cited as one of the most important factors affecting dairy farm profitability (van Arendonk, 1985), and these decisions are directly affected by fluctuations in milk price, salvage values, and replacement costs. Culling decisions are based primarily on milk production and partially on health status. Despite their economic importance, culling decisions are often made in a non-programmed fashion and based partly on the intuition of the decision maker (Lehenbauer and Oltjen, 1998). According to Compton et al. (2017) dairy industries and farmers need benchmarks for culling and mortality against which they can compare themselves, as well as improved understanding of the extent of any change and of any associated factors.

The objective of this paper is to assess different heifer replacement strategies in Slovakia by using the EkonMOD milk tool (link to the EkonMOD milk tool dedicated web page: http://madobis-sk.cvzv.sk/hd/), the decision support tool for dairy farm managements. The purpose of this webbased application is to support the economic performance of dairy farms and to actively seek sound and smart solutions intended primarily for Slovak conditions.

\section{DATA AND METHODS}

The result of complex evaluation of economic and production indicators is the assessment of the dairy farm efficiency. This approach also allows comparison between peer operations as well as, benchmarking on the farm level. The metric included in the evaluations are based on parameters describing the calves and replacement heifer rearing cost and production metric of liveweight and weight gains. The EkonMOD milk tool managements is used to evaluate the economic consequences of different managerial strategies. The specific module Number of heifers needed for replacement was developed to raise the awareness about replacement heifer rearing costs and it is used in this paper as a tool to evaluate specific economic and production parameters of selected dairy operation. The rationale of the EkonMOD milk tool approach (Záhradník, 2017) is based on the following list of parameters which is according to Daňo et al. (2007) fundamental to construction of dairy herd turnover economics evaluation and projections.

Parameters:

$P_{N C}$ New-born calf price;

$C_{N C}$ New-born calf cost;

$C_{S C}$ Cost to rear a selected calf;

$C_{W C}$ Cost to rear a weaned calf 6 (8) months;

$W_{W C}$ Average liveweight of weaned calf 6 (8) months;

$C_{S H}$ Cost to rear a selected heifer;

$C_{P H}$ Cost to rear a pregnant heifer;

$C_{S B}$ Cost to rear a selected bull;

$C_{C H}$ Cost to rear a first calving heifer.

When assessing the complex economic evaluation procedure, the Equations 1-8 are crucial. They represent the rationale of determining the cost of production within and during the rearing periods along with performed farm decisions in evaluated time period. They are supportive when establishing the framework for milk production system and husbandry systems optimization in line with consistency plans for economic and non-economic volatility. This also implies updating the break-even point of productions and to cycle these calculations to ensure that the dairy operation outputs and performance indicators meet the necessities determined by the market. Setting the minimal milk price to reach zero profitability or minimal milk yield per cow or total costs per cow per year then support the farm management to agile responds. Equations for parameters:

$$
\begin{aligned}
& C_{N C}=W_{N C} * P_{N C} \\
& C_{S C}=\frac{W_{S C}-W_{N C}}{G_{C L}} * C_{C}+P_{N C} \\
& C_{W C}=\left(180 * C_{C}\right)+P_{N C} \\
& W_{W C}=\left(180 * G_{C L}\right)+W_{N C} \\
& C_{S H}=\frac{W_{S H}-W_{W C}}{G_{H L}} * C_{Y C}+C_{W C} \\
& C_{P H}=\left(x_{1} * C_{Y C}\right)+\left[\left(x_{0}-x_{1}\right) * C_{P H}\right]+C_{W C} \\
& \text { where: } x_{1}=A_{F C}-330 \text { days } x_{0}=\frac{W_{S H}-W_{W C}}{G_{H L}} \\
& C_{S B}=W_{S B} * C_{F B W}=\frac{W_{S B}-W_{W C}}{G_{B L}} * C_{F B}+C_{W C} \\
& C_{C H}=\left(150 * C_{P H}\right)+\left(x_{1} * C_{Y C}\right)+C_{W C}
\end{aligned}
$$

Where:

$C_{C}$ Total cost per feeding day of calf;

$C_{Y C}$ Total cost per feeding day of young cattle;

$C_{P H}$ Total cost per feeding day of pregnant heifer;

$C_{F B}$ Total cost per feeding day of fattened bull;

$C_{F B W}$ Total cost per kg of liveweight of fattened bull;

$W_{N C}$ Average liveweight of new-born calves;

$W_{S C}$ Average liveweight of selected (slaughter) calves; $W_{S H}$ Average liveweight of selected (fattened) heifers;

$W_{P H}$ Average liveweight of selected (pregnant) heifers; 
$W_{S B}$ Average liveweight of selected bull;

$G_{C L}$ Average liveweight daily gain of calves;

$G_{H L}$ Average liveweight daily gain of replacement heifers;

$G_{B L}$ Average liveweight daily gain of fattened bulls; $A_{F C}$ Average age at first calving.

The EkonMOD milk tool continuously integrates specific applications developed in the sphere of dairy cow husbandry by the NPPC-RIAP into one platform under the title EkonMOD milk - Interactive model of a dairy farm, which analyses the input parameters of the breeding intensity, including specified parameters of reproduction and performance, and determines a detailed herd turnover and status of the animals for each category within the given farm. Balancing of the nutritional requirements and the nutritional content of the feed, which the breeder submitted into the model, is done automatically. Following that, the total requirements for feed as well as the necessary acreage of soil needed to grow the forage are determined. This analysis is expanded to include the required storage space and litter requirements. The analysis of total production of marketable products is then, in the context of the particular farm and its characteristics, supplemented by complex evaluation of the milk production costs. This specific module is also used in this paper as a tool to evaluate specific economic and production parameters of selected dairy operation.

For calculation, the application EkonMOD milk Interactive model of a dairy farm uses the reproduction and performance parameters input by the user and from this data, it determines herd turnover, status of the animals and nutritional requirements. The user inputs also the feed he plans to feed to the animals and the nutritional content of those. Nutritional requirements per animal category are generated by the application. User defines the portion of each feed in the feed ration and the application determines the difference in nutrient content in the feed ration and the nutritional needs of the animals. By combining the feeds, it is necessary to compose a feed ration in a way that minimises the differences (particularly in dry matter, fibre, Net Energy Lactation (NEL) and Protein Digestible in the Intestine (PDI). Based on the feed rations for each category of animals, the application calculates the total feed needed for a year, with $10 \%$ reserve in the case of fodder feeds. From this data, the amount of forage (in original matter) that needs to be grown is calculated. For each feed, the user inputs a coefficient for preservation and weight losses in preservation and storage. Coefficient for preservation defines the weight loss from harvest to preservation. Coefficient 1 is for the forages that are ensilaged after harvest as the original green matter (maize, sorghum, grain, etc.). Forages that are dried between harvest and ensilaging to higher dry matter content and lose weight are adjusted by coefficient 1.6 (alfalfa, clover, grasses, etc.; harvested at $20 \%$ dry matter content and ensilaged at $32 \%$ dry matter content). From the green matter yield, the application generates the acreage necessary to grow the forage.

Not all milk produced during the year is successfully sold. Therefore, the user defines the portion of produced milk that is sold. In manure storage, there are losses of weight, which depend on storage and manure treatment. When manure is layered regularly, the weight losses are around $40 \%$, in case of free field stores, the losses are higher - up to $60 \%$. The user defines the losses based on the storage of the manure. The application then calculates the actual amount of manure available for fertilization.

In order to determine the economy, the user inputs the prices of products, feed, litter and manure. To determine the depreciation expenses for the assets, the user defines either his own depreciation expenses for each category of animals or total depreciation expenses for cattle breeding and of the shares of each animal category on these expenses. To determine salary costs, the user has to define the number of employees treating the cattle and their monthly wages. Other direct costs (medications and disinfectants, other materials, repairs and maintenance, breeding and veterinary services) as well as operating costs (production and management) are defined by the user.

We consider perhaps the most important aspect, worth reiterating, to be the application's character of an open platform, which welcomes active participation in the form of feedback and suggestions for further development.

\section{Data}

The economic and production real input data was obtained from database developed by NPPC-RIAP - Institute for Animal Husbandry Systems, Breeding and Product Quality, best referring to the conditions in Slovak dairy farming systems. This detailed dataset (since 2000) enables the correct assessment of real-farm problems and opportunities based on farming system applied. Based on these data, the dairy sector is able to define the points of interest (for economic optimization and greenhouse gas mitigation agenda) with regard to specific dairy farming systems used. The real data case, referring to semiintensive dairy farm and typical Holstein dairy farm, will serve as a baseline for what-if scenarios in this paper.

\section{Scenario description}

The what-if scenarios 1 and 2 in this paper will deal with the suggested managerial changes during the calves rearing period, heifer selection and reduction of the AFC, leading to replacement heifer surplus or deficit. These scenarios will be using the specific module of the EkonMOD milk tool - Number of heifers needed for replacement. With this regard, the replacement heifer program is particularly important, and its primary goal is to breed these animals at an early age with optimal body weight to achieve easy calving with minimum investments (Fricke, 2004). Calving older heifers is subtracting money from profitability. Producers should raise only the number of replacement heifers needed, unless the additional heifers will be marketed (Bailey et al., 2009). The lastadditional scenario referring to the large scale Holstein farm will use the more complex module of the EkonMOD milk tool - Interactive model of a dairy farm. We will deal with the suggested reduction of the AFC, leading to reduction in the feeding days per heifer category and reduction in total cost to raise a heifer. 


\section{RESULTS AND DISCUSSION}

Resilient livestock production requires locally tailored solutions. Sustainable dairy farming is dependent on the agility of management to continuously tailor the operation according to the market projections, output and input price volatility, with respect to the animal welfare standards.

\section{Setting the general framework for herd turnover management}

We have used the EkonMOD milk tool module Number of heifers needed for replacement by using several herd specific metrics: If the annual replacement rate of first lactation cow depicted in Figure 1 is set to $35 \%$, and $25 \%$ for remaining stages of lactations in a 300 head herd, a minimum of 170 heifers in the pool, assuming a $4 \%$ attrition factor for stillbirths, $100 \%$ dairy cow natality, 5 $\%$ mortality of calves. With selection of calves' indicator set to $4 \%, 50 \%$ ratio of heifers born, heifer selection at $20 \%$, culled cows that die before disposal set to the value of $20 \%$ and AFC 24 months, proximately 64 pregnant heifers are needed. When calving is delayed to an age greater than 24 months, heifers are accumulating in the replacement pool. For every one-month increase in the AFC over 24 months, the replacement inventory numbers are increasing at a rate of $4.7 \%$ in this model. Figure 1 takes into account the inventory of heifers from birth through calving. Therefore, following the general logic of the herd turnover indicated in Table 1 , if a herd is calving 28 month old heifers with an average culling rate of first lactation cows $35 \%$ and remaining cows in herd with 25 $\%$, the number of replacement heifers on the farm is now increased from 170 to 199 heifers. This equates to 29 additional heifers or an increase of $17 \%$ in the total number of heifers consuming feed, labour, fuel, facilities, and management. In addition to this logic, the table below demonstrates the increase in heifers needed at various culling rates (Table 2) and the relationship between the culling rate, AFC, and increasing heifer inventory. Calving older heifers is subtracting money from profitability. Producers should raise only the number of replacement heifers needed, unless the additional heifers will be marketed (Bailey et al., 2009).

The current research indicates an average cost to raise a heifer $1824 €$ (Michaličková et al., 2015). A herd of 300 lactating cows with a culling rate of $25 / 35 \%$ will need to calve 88 heifers per 12 months. If the average calving age is 30 months, the increase in expenses is approximately $540 €$ per heifer for those 6 months over goal. This transforms to $47520 €$ loss per year in extra labour, feed and fuel. An additional loss in calving heifers at more than 24 months of age is the increase in heifer inventory numbers (Table 2). If producer $\mathrm{A}$ is calving heifers at 24 months of age per 300 cows and producer B is calving at 30 months of age, producer B will have additional heifers in his replacement pool to meet the same culling rate as producer A. The higher AFC accumulates the heifers in inventory. For each additional month over goal of 24 months, $4.7 \%$ more heifers are needed in replacement inventory in this model. If producer A needs 171 heifers in his heifer inventory for a 24-month turnover of heifers (from born to calving). Producer B, to meet the same culling rate, will need 214 heifers on his farm.

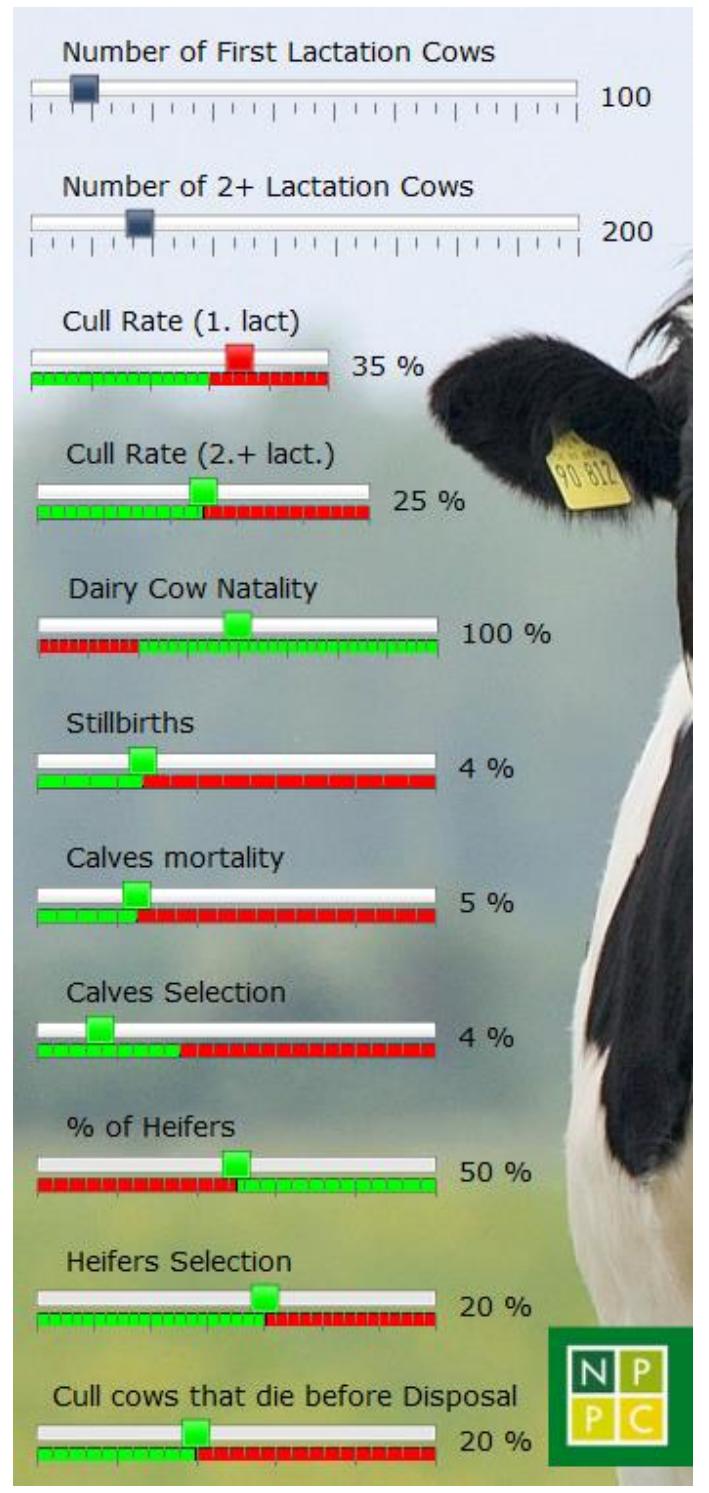

Fig. 1 EkonMOD milk model calibration

Tab. 1 Number of replacement for each AFC in a 300 cow herd

\begin{tabular}{lcccccc}
\hline Months & 24 & 26 & 28 & 30 & 32 & 35 \\
\hline Replacement heifers & 170 & 185 & 199 & 213 & 227 & 249 \\
\hline
\end{tabular}

Source: own calculations

Note: Total heifer inventory numbers for varying herd sizes at a 35\% replacement per year for first lactation cows and $25 \%$ replacement per year for cows at remaining lactation stages. Other rearing parameters are taken from the following assumption: $4 \%$ stillbirths, $100 \%$ dairy cow natality, $5 \%$ mortality of calves, selection of calves $4 \%, 50 \%$ ratio of heifers born, heifer selection 20 $\%$, culled cows that die before disposal $20 \%$. 
Tab. 2 Number of replacement heifers for various culling rates

\begin{tabular}{lc}
\hline Culling Rate & Increase in heifer pool numbers over 24 month calving age $\left.{ }^{\wedge}\right)$ \\
\hline $25 / 35^{*}$ & $170(20$ surplus heifers $)\left(32^{\wedge}\right)=202^{* *}(2$ deficit heifers $)$ \\
$26 / 36^{*}$ & $176(17$ surplus heifers $)\left(45^{\wedge}\right)=221^{* *}(6$ deficit heifers $)$ \\
$27 / 36^{*}$ & $180(15$ surplus heifers $)\left(46^{\wedge}\right)=226^{* *}(8$ deficit heifers $)$ \\
$27 / 37^{*}$ & $182(14$ surplus heifers $)\left(47^{\wedge}\right)=229^{* *}(9$ deficit heifers $)$ \\
$27 / 38^{*}$ & $184(13$ surplus heifers $)\left(48^{\wedge}\right)=232^{* *}(11$ deficit heifers $)$ \\
\hline
\end{tabular}

Source: own calculations

Note: Calving at 24 Months of Age. *Culling rates for second and following lactations/culling rates for first calving heifers. Other rearing parameters are taken from the following assumption: $4 \%$ stillbirths, $100 \%$ dairy cow natality, $5 \%$ mortality of calves, selection of calves $4 \%, 50 \%$ ratio of heifers born, heifer selection $20 \%$, culled cows that die before disposal $20 \%$. **Increase in heifer replacement numbers for various culling rates in 300 cow herd: First calf heifers calving at 30 months.

These 43 additional heifers are unnecessarily consuming feed and management (Table 1). Returns from this period down to 24 months could also represent generated income. If the $\mathrm{AFC}$ is reduced from 30 down to 24 months, the dairy operation could expect these additional heifers for potential sale, growth, or culling pressure on the lactating herd. This scenario means that in the first two years' heifer development is emphasized, expenses in feed and management are decreased by 47,520 $€$ per year, and $53,750 €$ worth of heifers are sold, bringing the total potential income for those two years to $101,270 €$ (Figure 2). Dairymen should not anticipate reducing the age to calving in several months, as experience indicates that it takes at least 18 to 24 months to decrease AFC to a goal of 24 months (Bailey et al., 2009).

\section{Sample farm approach}

We use the application EkonMOD milk tool when supporting the management decision. Moreover, we introduce the sensitivity analysis feature of the tool. We run several what-if scenarios and assess the impact on dairy farm performance. We consider sample dairy farms from the economic and performance indicator datasets of the NPPC-RIAP, referring to a typical semi-intensive dairy farm and a typical Holstein dairy farm. The economic impact of decreased AFC and improved indicators during rearing period are summarized in Table 4. The two alternative management approaches are considered. The sensitivity analysis in scenario 1 and 2 represent a typical problem occurring in dairy operation. The sample semi-intensive dairy farm used in this evaluation run an operation with 423 dairy cows. The culling indicator for first lactating cows reaching $36 \%$, and on second and next lactations $30 \%$ on average. The natality of cows is $95 \%$, with $7 \%$ stillbirth rate and $11 \%$ calve mortality. Calves selection at the level of $14 \%$ with ratio of heifers born $50 \%$ and $20 \%$ of cows dying before disposal resulted in a need for 290 heifers (from birth till calving) to maintain constant herd size. This performance is related to the 25.8 months of AFC ( 789 days). However, the operation did not fully meet the requirements for replacement heifer internally. The performance resulted in
31 heifer deficit, implying the purchasing those heifers from external sources on the market or degreasing the herd size. The what-if scenario 1 considers the decrease of average AFC in this dairy operation to 24 months (733 days). This management adjustment will lead to reduction of heifers' inventory needed for replacement. The preposition will decrease the amount of heifer need for replacement to 269 and parallel dilute the deficit to only 21 heifers. The what-if scenario 2 provides a next step in sensitivity analysis assuming improvements in rearing performance. The stillbirth rate decrease from $7 \%$ to $4 \%$, calves' mortality indicator decrease from $11 \%$ to $5 \%$ and calves and heifer selection decrease from $14 \%$ to $9 \%$ and $20 \%$ to $18 \%$ respectively, will cumulatively results in having 3 additional heifers for sale, while the number of heifers needed for replacement remaining the same.

Moreover, we can assess the financial aspects of this analysis. If we consider price for culled cow $590 €$, cost to raise a heifer $1500 €$, price for purchased heifer $1065 €$ in this operation, the real data case yielded the economic result of $29903 €$. The what-if scenario 1 decreasing the AFC by 56 days will generate $10961 €$ of additional profit and the what-if scenario 2 optimizing the rearing period resulting in $62794 €$ profit, which is almost doubling the original economic result of the sample dairy farm. The analysis is depicted in Figure 3.

Figure 4 outlines different perspective on the same situation within the sensitivity analysis. The reduction of AFC in the what-if scenario 1 also reduced the number of heifers needed for replacement from 290 to 269 heifers, also having the positive impact on the profitability resulting from these interrelations. In the what-if scenario 2 the AFC remained the same as in what-if scenario 1 (also the culling rates for the first and next lactation cows) meaning that the number of replacements needed was without any change. However, the improved performance during rearing period contributed with surplus heifers to the financial benefits doubling the original value coming from the real data case. 
Fig. 2 Screenshot of simulation example

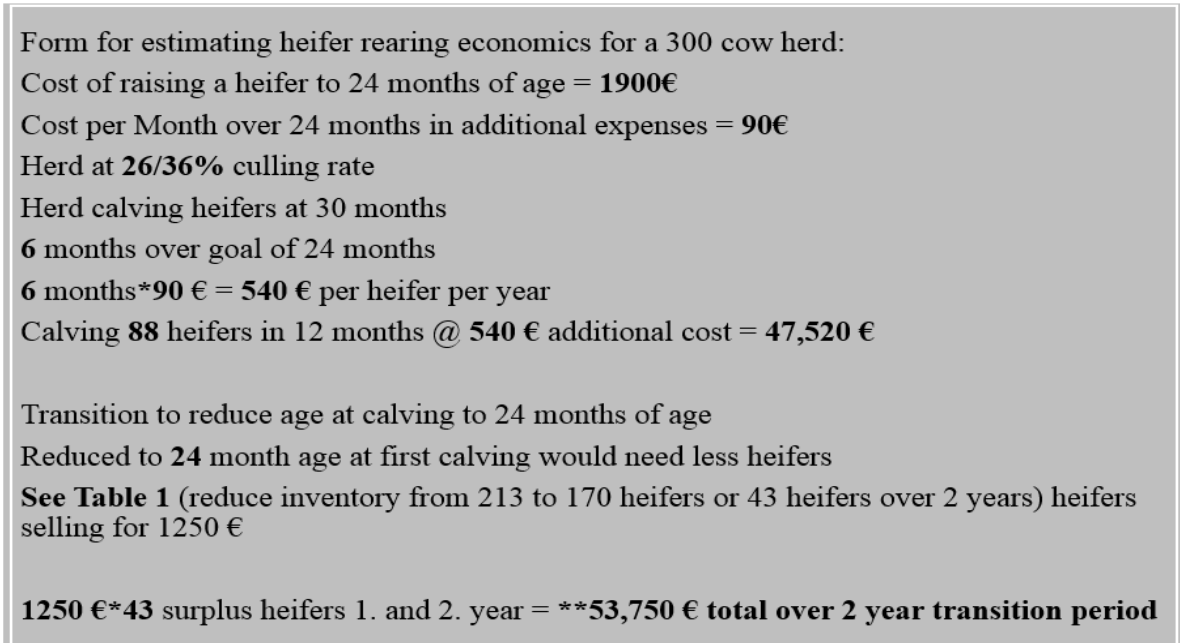

Source: Form adapted from Bailey et al. 2009, own calculations

Note: **One-time transition recovery of income decreasing from 30 Months to 24 Month. Typically accomplished over a 2-year period of time

Tab. 4 Sensitivity analysis - AFC and heifers (calves) rearing period

\begin{tabular}{lrrr}
\hline & Real data & What-if scenario 1 & What-if scenario 2 \\
\hline Dairy cows numbers & 423 & 423 & 423 \\
Culling (1. lactations) & $36 \%$ & $36 \%$ & $36 \%$ \\
Culling (remaining lactations) & $30 \%$ & $30 \%$ & $30 \%$ \\
Dairy cow natality & $95 \%$ & $95 \%$ & $95 \%$ \\
Stillbirths & $7 \%$ & $7 \%$ & $4 \%$ \\
Calves mortality & $11 \%$ & $11 \%$ & $5 \%$ \\
Calves selection & $14 \%$ & $14 \%$ & $9 \%$ \\
ratio of heifers born & $50 \%$ & $50 \%$ & $50 \%$ \\
Heifer selection & $20 \%$ & $20 \%$ & $18 \%$ \\
culled cows that die before disposal & $20 \%$ & $20 \%$ & $20 \%$ \\
AFC (days) & 789 days & 733 days & 733 days \\
Number of heifers needed for replacement & 290 & 269 & 269 \\
Replacement heifers surplus or deficit & -31 & -21 & 3 \\
\hline
\end{tabular}

Source: own calculations

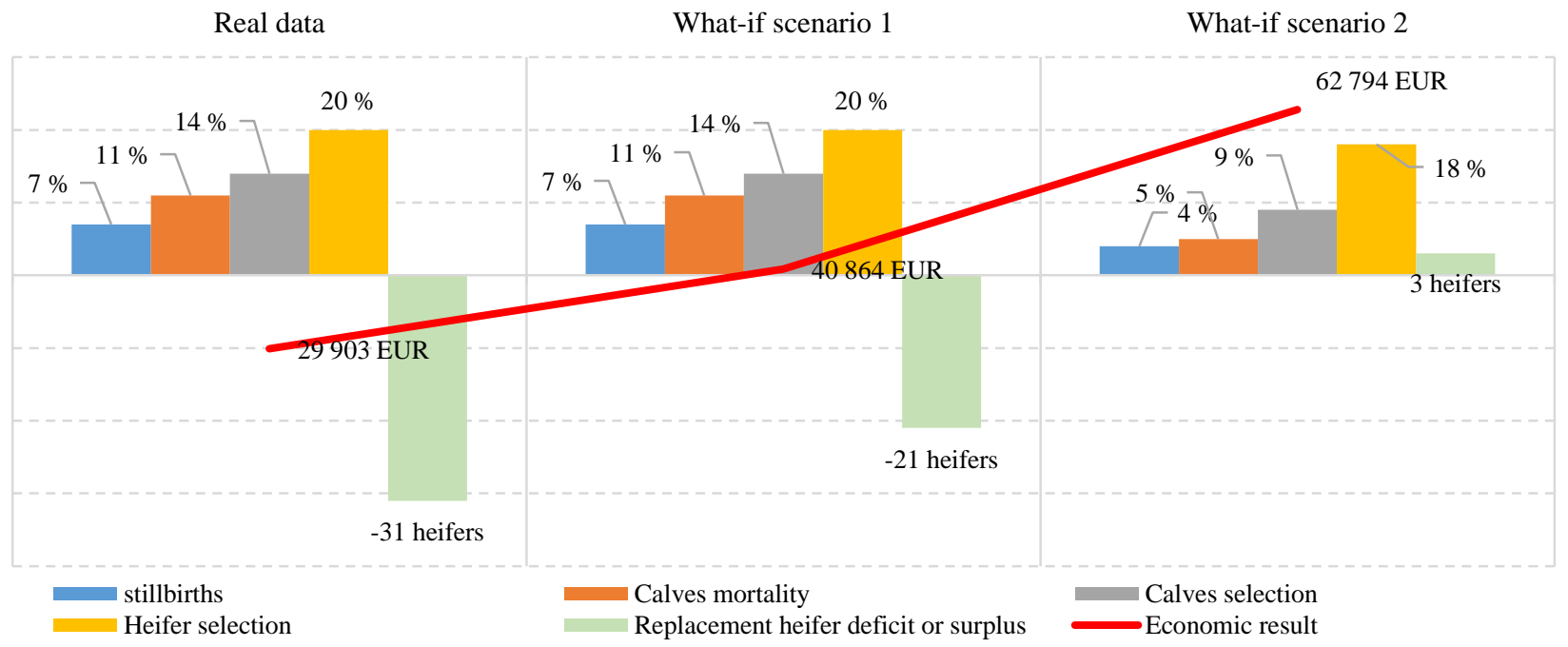

Fig. 3 Economic analysis - EkonMOD milk results I.

Source: own calculations 


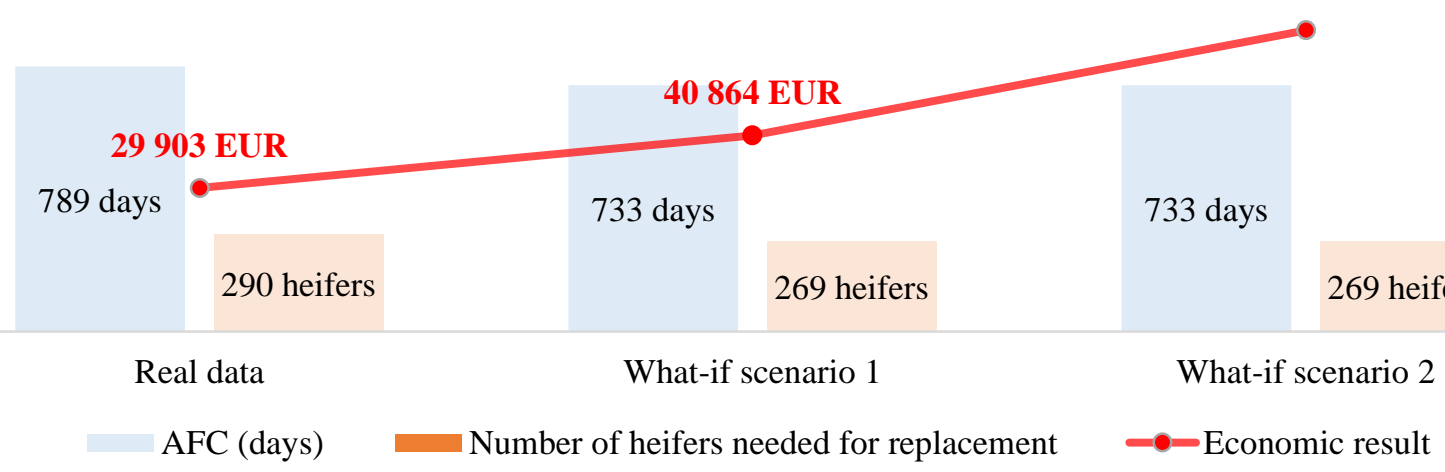

Fig. 4 Economic analysis - EkonMOD milk results II.

Source: own calculations

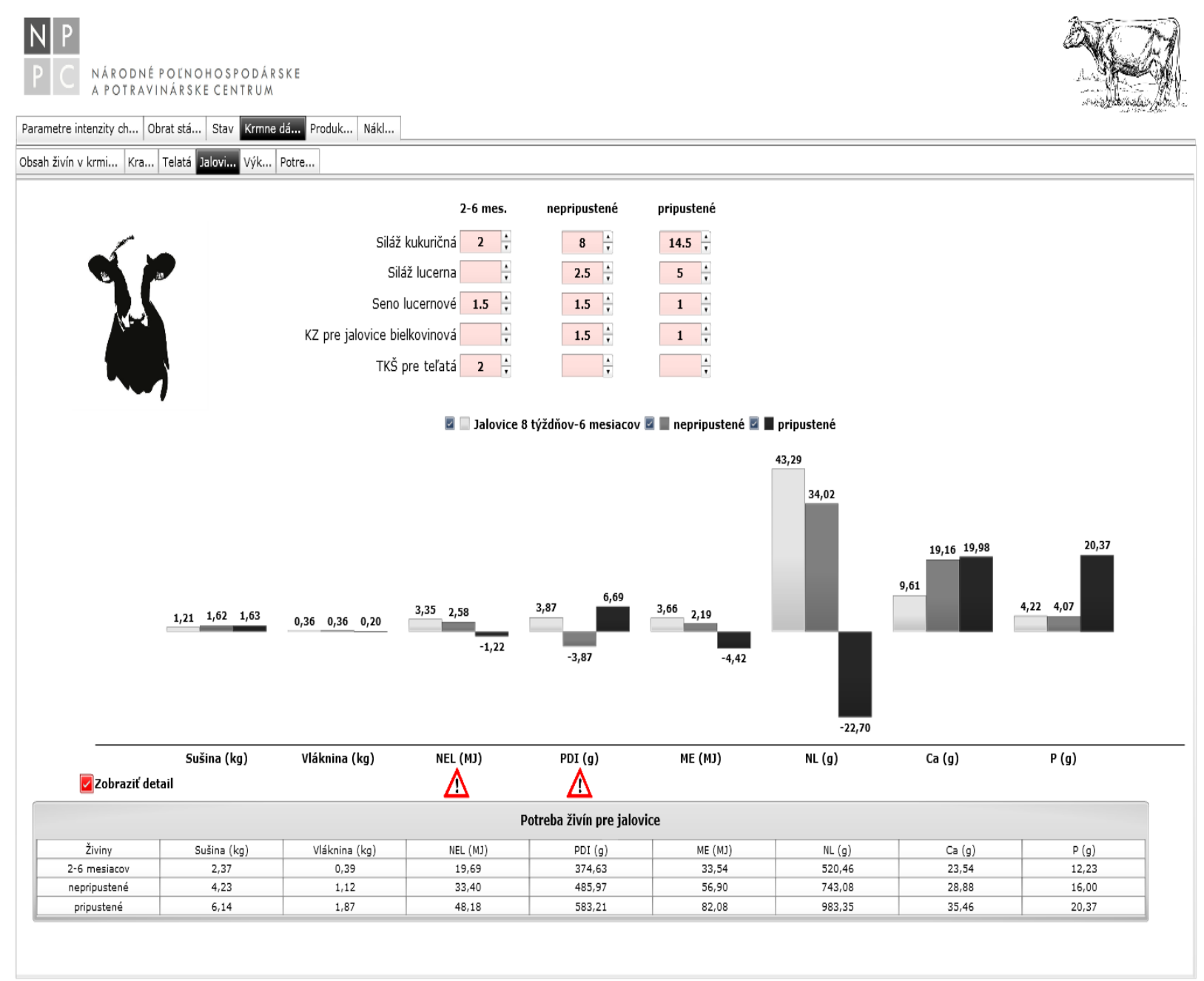

Fig. 5 Balancing the nutritional and energy content of the feed with heifers' requirements Source: EkonMOD milk - Interactive model of a dairy farm screenshot (2018)

The results for any input change proposed is easy accessible, without any need for additional calculation or script procedure, and visualised by interactive dashboard. Moreover, the application outcomes are more clearly visible, also respecting the interrelations logics and methodology used. To go more in detail, we will move to add more managerial scenarios to the AFC sensitivity analysis and see the economic results for this modifications.

We have dealt with the optimal bodyweight (BW) of first calving heifers given the specific AFC. This structured analysis underpins the wider framework of economic optimization of individual dairy production system. The previous work in the sensitivity analysis 
documented that lower AFC implies fewer replacement heifer needed. However, the reduction schemes are very farm dependent and directly linked to the intensity of calves and heifer growth. The critical point is the optimal combination of daily weight gain leading to the optimal body condition score. The optimal BW of first mated heifers should vary between $300-360 \mathrm{~kg}$ reaching approximately $55 \%$ of mature cow BW. Moreover, heifer should reach $610 \mathrm{~kg}$ of BW when first calving. Every $1 \mathrm{~kg}$ below this threshold value implies $2.5 \mathrm{~kg}$ reduction in milk production in the first lactations (Fetrow et al., 1986).

In the last more detail focused scenario presented in this paper, we will consider the Holstein dairy farm with 500 productive dairy cows with an average annual milk yield of 10,000 litres per cow. The applied breeding system was specified by entering more than 200 different input parameters. Running the more complex Interactive model of a dairy farm of the EkonMOD milk tool brought the result, that the reduction in the AFC calving from 26 to 24 months would reduce the number of feeding days in the heifer category by 12410 days, which, even by taking into account the consequent change in weight gain of heifers, means a reduction in total costs of at least 22000 $€$, while the total cost of rearing a heifer (in 7th month of pregnancy) would be reduced accordingly by $120 €$ to $1590 €$, in this scenario. The associated modification of the nutritional requirements was generated by the program. The dynamic graph of the application, based on the proposed feeding doses for all heifers' categories, a prespecified nutrient and energy content in individual feeds is automatically compiled for the heifers at the age of 8 weeks to 6 months, un-mated and mated (pregnant) heifers. If the nutritional content of the feed doses in relation to the nutritional requirements is ideal, the bar graph will not be visible and feeding dosses will be balanced optimally. An illustrative example of how the application works with a partially unbalanced feeding doses of the considered breeding system is shown on the enclosed screenshot of the application in Figure 5. The red warning symbol additionally visually highlights the difference for dry matter, fibre, NEL and PDI for all age groups of heifers, automatically.

\section{CONCLUSION}

Following the logic of the general framework for herd turnover management, the example simulation of reduction of AFC from 30 down to 24-months result in additional heifers for potential sale, growth, or culling pressure on the lactating herd. This means that in the first two years' heifer development is emphasized, expenses in feed and management are decreased by 47,520 $€$ per year, and $53,750 €$ worth of heifers are sold, bringing the total potential income for those two years to $101,270 €$.

The reduction of AFC in the what-if scenario 1 referring to semi-intensive dairy farm from the economic and performance indicator datasets of the NPPC-RIAP reduced the number of heifers needed for replacement from 290 to 269 heifers, also having the positive impact on the profitability resulting from these interrelations.

In the what-if scenario 2 the AFC remained the same as in what-if scenario 1 (also the culling rates for the first and next lactation cows) meaning that the number of replacements needed was without any change. However, the improved performance during rearing period contributed with surplus heifers to the financial benefits doubling the original value coming from the real data case. The 172 heifers calving per year at the age of 789 days with BW reaching only $80 \%$ will generate an economic loss $-35 €$ on a per cow basis. If the management could improve the performance during the rearing period of both calves and heifers by reducing the average AFC to 733 days ( 24 months), the economic loss will be only $-25 €$ per cow (reduction $40 \%$ ). Moreover, if the dairy farm management could increase the BW of first calving heifers from $80 \%$ to $84 \%$ of average BW of mature cow in the herd (assuming optimum at $85 \%$ ), the economic loss will now be only $-6 €$ per cow (reduction $70 \%$ ).

In the last - additional scenario, the reduction in the AFC from 26 to 24 months in the 500 Holstein dairy cow herd from the economic and performance indicator datasets of the NPPC-RIAP would reduce the number of feeding days in the heifer category by 12410 feeding days, which, even by taking into account the consequent change in weight gain of heifers, means a reduction in total costs of at least $22000 €$, while the total cost of rearing a heifer (in 7th month of pregnancy) would be reduced accordingly by $120 €$ to $1590 €$.

The idea behind the application is to not only evaluate the existing state but to provide also an analysis of possible changes, which the farmer is considering or forced to implement. The short term market volatility will likely persist so the farmer has to focus on long-term productivity. Effective interdisciplinary cooperation on development of the modules represents added value for the farmer, who is given the opportunity to generate in one place in minimum time his own business analysis, which will concretize the options and limits in the given financial framework. The accuracy, independence and timeliness of business analyses is always based on the relevancy of input parameters, but also on their character, which is that of a business plan. The versatility of the core application offers potential use in numerous areas in the future including the possible adaptation of the tool for use in the pig, sheep and beef cattle sector. This approach aims to serve as a handy way to improve decision-making regarding the dynamics of the dairy herd structure and market volatility and it opens the dairy business to greater control of what is doing and the same time knowing the financial footprint of it.

\section{Acknowledgments:}

The authors acknowledge the financial support from the Slovak Research and Development Agency (Grant No. APVV-16-0321), the Czech Science Foundation (GACR) (Grant No. 16-02760S) and by the Scientific Grant Agency VEGA (Grant No. 1/0928/17 and No. 1/0666/17).

\section{REFERENCES}

AUBERT, B. A., SCHROEDER, A. and GRIMAUDO, J. (2012). IT as enabler of sustainable farming: An empirical analysis of farmers' adoption decision of precision 
agriculture technology. Decision Support Systems 54, 510-520 DOI: $10.1016 /$ j.dss.2012.07.002

BAILEY, T. L. and CURRIN, J. (2009). Heifer Inventory and the Economics of Replacement Rearing. Extension Specialist, Virginia-Maryland Regional College of Veterinary Medicine, Virginia Tech, publication 404-287 BRESTENSKÝ, V. and MIHINA, Š. (2006) Organizácia a technológia chovu mliekového hovädzieho dobytka. Publikácie SCPV Nitra, 14, ISBN 80-88872-53-7

BURRELL, A. (2004). The 2003 CAP reform: Implications for the EU dairy sector. Outlook on Agriculture 33, 15-25.

CEAS (2010). The Environmental Impact of Dairy Production in the EU: Practical Options for the Improvement of the Environmental Impact: Final Report. CEAS 1779/BDB. Centre for European Agricultural Studies (Wye, UK) and the European Forum on Nature Conservation and Pastoralism. 11/2010 http://ec.europa.eu/environment/agriculture/pdf/dairy.pdf COMPTON, C. W. R., HEUER, C. THOMSEN, P. T., CARPENTER, T. E., PHYN, C. V. C. and MCDOUGALL, S. (2017) Invited review: A systematic literature review and meta-analysis of mortality and culling in dairy cattle. J. Dairy Sci. 100:1-16, DOI: 10.3168/jds.2016-11302

DAŇO, J., HUBA, J., KRUPOVÁ. Z., KRUPA, E. (2007) Vývoj ekonomiky chovu dobytka na začiatku XXI. Storočia. 2007. Nitra: Slovenské centrum pol'nohospodárskeho výskumu, $70 \mathrm{~s}, 11$ tab. príl. ISBN 978-80-88872-61-0

DE JONG. (2013). Sustainable Dairy Production. March 2013, Wiley-Blackwell. ISBN: 978-0-470-65584-9. DOI: 10.1111/1471-0307.12095

DRIES, L., GERMENJI, E.N., NOEV, M., and SWINNEN, J.F. (2009). Farmers, Vertical Coordination, and the Restructuring of Dairy Supply Chains in Central and Eastern Europe", World Development, 37 (11): 17421758. DOI: $\underline{10.1016 / j . w o r l d d e v .2008 .08 .029}$

FETROW, J., NORDLUND, K. V. and NORMAN, H. D. (2006). Invited Review: Culling: Nomenclature, Definitions, and Recommendations. J. Dairy Sci. 89:1896-1905. DOI: 10.3168/jds.S0022-0302(06)72257$\underline{3}$

GARMESTANI, A.S., ALLEN, C.R., MITTELSTAEDT, J.D., STOW, C.A. and WARD, W.A. (2006) Farm size diversity, functional richness, and resilience. Environment and Development Economics 11: 533-551. Cambridge University Press. DOI: 10.1017/S1355770X06003081

KORTE, M., LEE, K. and FUNG, C.C. (2012) Sustainability in Information Systems: Requirements and Emerging Technologies. In Proc. 2012 Int. Conf. on Innovation, Management and Technology Research (ICIMTR2012), Malacca, Malaysia, 21-22 May, 2012, pp. 481-485. DOI: 10.1109/ICIMTR.2012.6236443
LEHENBAUER, T. W. and J. W. OLTJEN. (1998). Dairy cow culling strategies: making economical culling decisions. J Dairy Sci. 1998 Jan;81 (1):264-71. DOI: 10.3168/jds.S0022-0302(98)75575-4

MELVILLE, N.P. (2010) Information Systems Innovation for Environmental Sustainability. MIS Quarterly, 34(1), $1-21$

MICHALIČKOVÁ, M., Z. KRUPOVÁ, Z., KRUPA, E., ZÁHRADNÍK, M. (2015) Ekonomická perspektíva výroby mlieka v roku $2014 \mathrm{v}$ analyzovaných chovoch SR. In: Rol'nícke noviny : odborný týždenník - príloha Dojnice. - ISSN 0231-6617. - Roč.85, č.42 (2015), s. 7-8.

NEWMAN, S., LYNCH, T. and PLUMMER, A. A. (2000). Success and failure of decision support systems: learning as we go. Journal of Animal Science 77, 1-12. DOI: $10.2527 /$ jas2000.77E-Suppl1e

PERRINGS, C. (1998). Resilience in the dynamics of economy-environment system. Environment and Resource Economics, 11(3-4): 503-520.

PETRIKOVIČ, P. - SOMMER, A. (2002). Potreba živín pre hovädzí dobytok, ovce a kozy. Publikácia, VÚŽV Nitra, $65 \mathrm{~s}$.

POWER, D.J. (2002) Decision support systems: Concepts and resources for managers. Westport, Connecticut: Quorum Books

ROGERS, C. A., FITZGERALD, A. C., CARR, M. A., COVEY, B. R., THOMAS, J.D. and LOOPER, M. L. (2004). On-Farm management decisions to improve beef quality of market dairy cows. Journal of Dairy Science 87, 1558-1564. DOI: $10.3168 / j d s . S 0022-0302(04) 73308-1$

TURBAN, E., ARONSON, J.E., LIANG, J.E. and SHARDA, R. (2007). Decision support and business intelligence systems (8th ed.). Upper Saddle River, New Jersey, USA: Pearson, Prentice Hall

VAN ARENDONK, J.A.M. and A.A. DIJKHUIZEN. (1985) Studies on the replacement policies in dairy cattle. III. Influence of variation in reproduction and production. Livestock Production Science 13.333- 349. DOI: $\underline{10.1016 / 0301-6226(85) 90025-9}$ 